\author{
EVS25 \\ Shenzhen, China, Nov 5-9, 2010
}

\title{
Evaluation of Environmental-friendliness of Waseda Advanced Electric Micro Bus
}

\author{
Yushi Kamiya, Kimihiko Sato, Yasuhiro Daisho \\ Waseda University, 55S-704, 3-4-1 Ohkubo, Shinjuku, Tokyo, JAPAN, kamiya@waseda.jp
}

\begin{abstract}
The Waseda Advanced Electric Micro Bus (WEB) has been developed and tested for convenient regional public transportation. By adopting an advanced hybrid electric power supply system (Nickel Sodium Chloride Battery \& Super capacitor for WEB-1, Nickel Sodium Chloride Battery \& Li-ion Battery for WEB-2) and related key components, significant improvements in energy consumption and $\mathrm{CO}_{2}$ emissions have been achieved, compared to that of an equivalent diesel micro bus.
\end{abstract}

Keywords: Electric Vehicle, Bus, $\mathrm{CO}_{2}$ Emissions

\section{Introduction}

In recent years, much has been talked about regarding environmental and energy issues, including the depletion of fossil fuels, as well as global warming and air pollution problems caused by the exhaust gases from various power sources, Automobile manufacturers around the world are being called upon to develop vehicles equipped with cleaner power sources instead of the conventional internal combustion engine.

Alternative-fuel vehicles must meet the following requirements: 1: Reduction of energy consumption and discharge of carbon dioxide and other harmful emissions from the time of manufacture until after they are operated on the road. 2: The vehicle must use a type of fuel that can be supplied continuously, with the possibility of having supply facilities everywhere. Many years have been spent on the research and development of electric vehicles, as one of the candidates for alternative fuel systems. However, such vehicles have not come into widespread use, as they have not reached a level that can adequately meet cost, power storage, and charging performance requirements [1].

The Waseda Advanced Electric Micro Bus (WEB) has been developed as a response. By limiting the use of batteries to a fixed route bus, the WEB resolves the shortcomings of conventional electric automobiles. Furthermore, verification tests were conducted on public roads in several regions that featured different characteristics. Stated in more concrete terms, the low-carbon effect and the energy usage cost of the electric-powered bus were evaluated in comparison to a diesel engine bus. As a result, it was confirmed that there were large differences in the environmental friendliness of the two vehicles, such as the energy consumption rate of the WEB and the amount of $\mathrm{CO}_{2}$ emissions, depending on the region where the experiment was conducted. This paper summarizes and presents the actual measurement results from each region as well as observations on the differences in environmental friendliness between the different regions.

\section{Experimental Vehicle WEB}

\subsection{Specifications}

The advanced electric micro bus developed through the present research project is called the Waseda Advanced Electric Micro Bus, or WEB. The WEB uses a Poncho, a compact, low-floor diesel bus made by Hino Motors, Ltd., as its base vehicle. Parts including the engine, exhaust pipe, 
and the like were removed, and, to create the electric micro bus, electric automobile components such as a motor and batteries were installed. Figure 1 shows the WEB, and Table 1 shows the specifications of the development vehicles.

The main battery is a Nickel Sodium Chloride Battery (ZEBRA battery), which is a type of a molten salt battery. The battery offers the following characteristics: high energy-weight density (virtual equal to lithium ion batteries), long lifetime (approximately twice that of lithium ion batteries), and low cost (at present, approximately $1 / 20$ th the cost of lithium ion batteries). Together with this battery, WEB-1 was also provided with a super capacitor and a WEB-2 also used a Li-ion battery with superior quick charging and discharging characteristics. This further improves the vehicle's powering and regenerative performance [2].

The aforementioned components were installed on the base vehicle, thus converting it into an electrically-powered bus [3]. Figure 2 shows the power system configurations of WEB-1 and WEB-2.

\subsection{Performance Evaluations of WEB}

A classic dynamometer test was performed to measure the fuel consumption performance and the like. The test equipment on the chassis dynamometer used for the running experiment is shown in Figure 3. The same type of test was applied to both the base vehicle and WEB-1 on the next conditions. The rolling load coefficient value was $0.01 \mathrm{~N} / \mathrm{N}$. The air resistance coefficient value was $0.0274 \mathrm{~N} /(\mathrm{km} / \mathrm{h})^{2} / \mathrm{m}^{2}$. The driving modes consisted of the M15 mode and a modified JE05 mode, as shown in Figure 4. Considering that WEB is operated on a bus route, the modified JE05 mode consists of the urban driving portion of the JE05 mode converted to a maximum speed of $40 \mathrm{~km} / \mathrm{h}$

Table 2 shows the fuel consumption and $\mathrm{CO}_{2}$ emissions calculations obtained from WEB- 1 and the base diesel vehicle (Poncho). Figure 5 shows the results of comparative evaluations performed on both vehicles. It was calculated that WEB-1 could reduce close to 70 percent of $\mathrm{CO}_{2}$ emissions.

\section{Verification Tests on Public Roads}

Up to now, verification tests have been conducted on public roads in several cities that have different characteristics. These different geographic characteristics included such things as the average driving speed, the degree of stop-andgo driving due to traffic, and the amount of uphill and downhill driving. Basic data, such as the amount of energy that was consumed, was measured as the buses were driven through these different geographic characteristics and then evaluated. A conceptual diagram outlining how this data was collected is shown in Figure 6. Details of the cities and regions where the verification testing on public roads was conducted are listed in Table 3. "shuttle run" is a round-trip run in which no bus stops were established along the driving route.

\section{1 $\mathrm{CO}_{2}$ Emission Rate and Energy Usage Cost}

The velocity, state of charge (SOC) and height histories for each verification test road is shown in Figures 7 to 10 . The data analyzed here is the data when the air conditioning was not used. Table 4 lists the results of the running tests in each region. The time during which the buses were stopped at traffic lights or bus stops is also included in the running time as an indicator of the traffic conditions in each region. In addition, the number of bus stops excludes the starting point of the run, but does include the final destination point.

The energy consumption rate was calculated using Equation (1). The capacity of the batteries in the WEB-1 was $18.9 \mathrm{kWh}$ and in the WEB-2 it was $21.2 \mathrm{kWh}$.

$$
r_{\text {energy }}=\frac{d}{B C A P \cdot \frac{-\triangle S O C}{100}}
$$

where,

$r_{\text {energy: }}$ energy consumption rate $[\mathrm{km} / \mathrm{kWh}]$

$d$ : travel distance $[\mathrm{km}]$

$B C A P$ : battery capacity $[\mathrm{kWh}]$

$\triangle S O C$ : amount of SOC change [\%]

The $\mathrm{CO}_{2}$ emission rate for an electric-powered vehicle was calculated using Equation (2).

$$
r_{\mathrm{CO} 2}=\frac{a_{\mathrm{CO} 2}}{r_{\text {energy }}}
$$

where,

$r_{\mathrm{CO} 2}: \mathrm{CO}_{2}$ emission rate $\left[\mathrm{kg}-\mathrm{CO}_{2} / \mathrm{km}\right]$ $a_{\mathrm{CO} 2}: \mathrm{CO}_{2}$ emission coefficient $\left[\mathrm{kg}-\mathrm{CO}_{2} / \mathrm{kWh}\right]$

The equation used to find the $\mathrm{CO}_{2}$ emission coefficient in this case is shown in Equation (3). The value used for the amount of $\mathrm{CO}_{2}$ emitted for each $1 \mathrm{kWh}$ of electric power generation was $0.375 \mathrm{~kg}-\mathrm{CO}_{2} / \mathrm{kWh}[4]$. 


$$
\begin{aligned}
a_{\mathrm{CO} 2} & =\frac{m}{\eta_{\text {transmit }} \cdot \eta_{\text {charg } e}} \\
& =\frac{0.375}{0.92 \cdot 0.95} \\
& =0.429
\end{aligned}
$$

where,

$m$ : amount of $\mathrm{CO}_{2}$ emitted for each $1 \mathrm{kWh}$ of electric power generation $=0.375 \mathrm{~kg}-\mathrm{CO}_{2} / \mathrm{kWh}$ $\eta_{\text {transmit }}$ : electric power transmission efficiency $=$ 0.92

$\eta_{\text {charge }}$ : charging efficiency $=0.95$

The percent reduction in well-to-wheel $\mathrm{CO}_{2}$ emissions due to the conversion to electric power from a diesel engine was calculated using Equation (4).

$$
p_{\mathrm{CO} 2}=\frac{r_{\mathrm{CO} 2}^{\prime}-r_{\mathrm{CO} 2}}{r_{\mathrm{CO} 2}^{\prime}} \cdot 100
$$

where,

$p_{\mathrm{CO} 2}$ : percent reduction in well-to-wheel $\mathrm{CO}_{2}$ due to conversion to electric power [\%] $r^{\prime} \mathrm{CO}_{2}$ : original $\mathrm{CO}_{2}$ emission rate $\left[\mathrm{kg}-\mathrm{CO}_{2} / \mathrm{km}\right]$

The value used for the original $\mathrm{CO}_{2}$ emission rate (the $\mathrm{CO}_{2}$ emission rate of the base diesel vehicle) was $0.38 \mathrm{~kg}-\mathrm{CO}_{2} / \mathrm{km}$. This value was measured in the laboratory by a chassis dynamometer test using the M15 mode.

The energy usage cost per $1 \mathrm{~km}$ for an electric vehicle was calculated using Equation (5). The cost of electric power for battery charging during the daytime was assumed to be $20 \mathrm{yen} / \mathrm{kWh}$ and 8 yen/kWh during nighttime. The cost of diesel fuel was assumed to be 93 yen/L. The fuel consumption rate of the diesel engine vehicle was found to be $7.42 \mathrm{~km} / \mathrm{L}$ in M15 mode according to the results of the chassis dynamometer test. Therefore, the original energy usage cost (the energy usage cost of the base diesel vehicle) is 13 yen $/ \mathrm{km}$.

$$
C=\frac{C_{\text {charge }}}{r_{\text {energy }}}
$$

where,

$C$ : energy usage cost per $1 \mathrm{~km}$ [yen $/ \mathrm{km}]$ $C_{\text {charge }}$ : charging cost per $1 \mathrm{kWh}[\mathrm{yen} / \mathrm{kWh}]$

The percent reduction in well-to-wheel energy usage cost due to the conversion to electric power from a diesel engine was calculated using Equation (6).

$$
p_{\text {cost }}=\frac{C^{\prime}-C}{C^{\prime}} \cdot 100
$$

where,

$p_{\text {cost }}:$ percent reduction in well-to-wheel energy usage cost due to conversion to electric power [\%] $C^{\prime}$ : original energy usage cost [yen $\left./ \mathrm{km}\right]$

The $\mathrm{CO}_{2}$ emission rate is one indicator that shows the environmental friendliness in each region. The results of calculating the well-towheel $\mathrm{CO}_{2}$ emission rate for each chassis dynamometer test and each region are shown in Figure 11 When these results were compared to the results from the chassis dynamometer test in M15 mode for the diesel engine vehicle, it was confirmed that converting the fixed route buses in each region to run on electric power made it possible to reduce the $\mathrm{CO}_{2}$ emissions by approximately 40 to $70 \%$ (the average was approximately 59\%). However, the driving conditions of the buses were different so, strictly speaking, a simple comparison cannot be made. Furthermore, it was also confirmed that there was a great difference in the $\mathrm{CO}_{2}$ emission rate of the electric-powered buses during the time of the test runs depending on the region where the test was being conducted.

The results of calculating the well-to-wheel energy usage cost per $1 \mathrm{~km}$ for each chassis dynamometer test and each region are shown in Figure 12. These results were compared to the results from the chassis dynamometer test in M15 mode for the diesel engine vehicle. It was found that a reduction in the energy usage cost of approximately 10 to $60 \%$ (the average was approximately $40 \%$ ) could be expected when using daytime charging and a reduction of approximately 60 to $90 \%$ (the average was approximately $76 \%$ ) could be expected when using nighttime charging. However, it was confirmed that there was also a great difference in the energy usage cost depending on the region where the test was being conducted, the same as in the case of the $\mathrm{CO}_{2}$ emission rate.

\subsection{Average Velocity and Energy Consumption Rate}

In an aim to make electric automobiles commercially viable, it is thought that popularizing these vehicles at an even earlier stage can be promoted by identifying the geographic and traffic characteristics of those regions that make sufficient use of the performance of electric vehicles. Therefore, an examination was conducted on the relationship between the average velocity in each region and the energy consumption rate by conducting 
verification testing on public roads as an initial investigation.

It was found that there is a tendency for the energy consumption rate to improve as the average velocity increases. However, it is predicted that once the velocity exceeds a certain value, the running efficiency will naturally decrease due to the influence of air resistance. Therefore, simulations were conducted at each running velocity of the WEB in order to investigate the relationship between the velocity and the energy consumption rate.

\subsubsection{Simulations at Each Running Velocity of WEB}

An electric vehicle running program was created that can output values such as the voltage, current, and energy consumption at each unit in time by entering the electric vehicle specifications, running conditions, and velocity history at each unit in time during the run. This was then used to conduct simulations at each running velocity of the WEB. The method of calculating the drive force is shown in Equations (7) to (9). In this investigation it was assumed that the vehicle is running at a constant speed over a flat, even road so the only types of resistance that will exert a direct influence on the drive force are the air resistance and the rolling resistance. Furthermore, the electric power consumption of auxiliary devices was fixed at $1200 \mathrm{~W}$.

$$
F_{\text {drive }}=F_{\text {acc }}+F_{\text {air }}+F_{\text {roll }}+F_{\text {slope }}
$$

where,

$F_{\text {drive }}:$ drive force $[\mathrm{N}]$

$F_{a c c}$ : acceleration resistance $[\mathrm{N}]$

$F_{\text {air }}:$ air resistance $[\mathrm{N}]$

$F_{\text {roll }}$ : rolling resistance $[\mathrm{N}]$

$F_{\text {roll }}$ : hill-climbing resistance $[\mathrm{N}]$

$$
F_{\text {air }}=\frac{1}{2} C d \cdot \rho \cdot A \cdot v^{2}
$$

where,

$F_{\text {air: }}$ : air resistance $[\mathrm{N}]$

$C d$ : air resistance coefficient $=0.4$

$\rho:$ air density $=1.184 \mathrm{~kg} / \mathrm{m}^{3}$

$A$ : frontal area $=6.448 \mathrm{~m}^{2}$

$v$ : running velocity $[\mathrm{m} / \mathrm{s}]$

$$
F_{\text {roll }}=\mu \cdot M_{\text {gross }} \cdot g
$$

where,

$F_{\text {roll: }}$ rolling resistance $[\mathrm{N}]$

(This is zero when the vehicle is stopped.)

$\mu$ : rolling: resistance coefficient $=0.01$

$M_{\text {gross }}$ : gross vehicle mass $[\mathrm{kg}]$

$\mathrm{g}$ : acceleration of gravity $=9.81 \mathrm{~m} / \mathrm{s}^{2}$
The simulation results for the energy consumption rate per $1 \mathrm{kWh}$ at each velocity are shown in Figure 13. From the results it was found that the ideal value for the energy consumption rate was attained when the vehicle velocity was $23 \mathrm{~km} / \mathrm{h}$. The reason for this is related to all three elements: the air resistance, the rolling resistance, and the electric power consumption of auxiliary devices. The energy consumption per $1 \mathrm{~km}$ at each velocity for each of these three elements is shown in Figure 14. The energy consumption due to the rolling resistance is only influenced by the total efficiency of the motor and therefore there is very little change in this energy consumption at any velocity. However, at low velocities the running time becomes longer and so the energy consumption due to the auxiliary devices becomes large, while at high velocities the energy consumption due to the air resistance becomes large. The energy consumption rate of the WEB reaches the ideal value at approximately $23 \mathrm{~km} / \mathrm{h}$ due to the influence from all three of these elements.

\subsubsection{Simulation Values and Actual Measured Values}

A comparison of the relationship between the average velocity and the energy consumption rate of WEB in each region and the simulations at each running velocity are shown in Figure 15 . The blue plots are urban areas (provincial), the red plots are urban areas (city), the green plots are residential areas, and the black plot is result from chassis dynamometer test. The black solid curve is the result of the simulations at each running velocity, and the black dotted curve is 0.6 times the rates of it. It was confirmed that the results for the rates of electric power consumption that were obtained from the verification testing on public roads almost correspond with values that were approximately 0.6 times the rates of electric power consumption at each average velocity in the simulation results. The reason the actual measured values are lower than the simulation results in all of the regions is that there was a large influence from the energy consumption during acceleration and also from the incline gradient of the running routes.

Therefore, the results above indicated that the energy consumption rate, which is one indicator used to evaluate the environmental friendliness of electric vehicles, is strongly related to the average velocity of the vehicle along the running route in the region where it is driven. 


\section{Conclusion}

The following three points $\backslash$ are the main results obtained from the verification testing on public roads that was conducted with the WEB that was developed.

1. It was confirmed that it is possible to reduce the amount of $\mathrm{CO}_{2}$ emissions by approximately 40 to $70 \%$ (the average was approximately $59 \%$ ) by converting a diesel powered micro bus to run on electric power.

2. It was confirmed that it is possible to reduce the energy usage cost by approximately 10 to $60 \%$ (the average was approximately 40\%) when using daytime charging and by approximately 60 to $90 \%$ (the average was approximately $76 \%$ ) when using nighttime charging.

3. It was found that based on the results from the simulations of the development vehicle at each running velocity, the ideal value for the energy consumption rate was attained at an average velocity of approximately $23 \mathrm{~km} / \mathrm{h}$ due to the tradeoff between the air resistance and the electric power consumption of the auxiliary devices. This trend corresponded to the results of actual measurements from the verification testing on public roads conducted in each region when these results were grouped by average velocity.

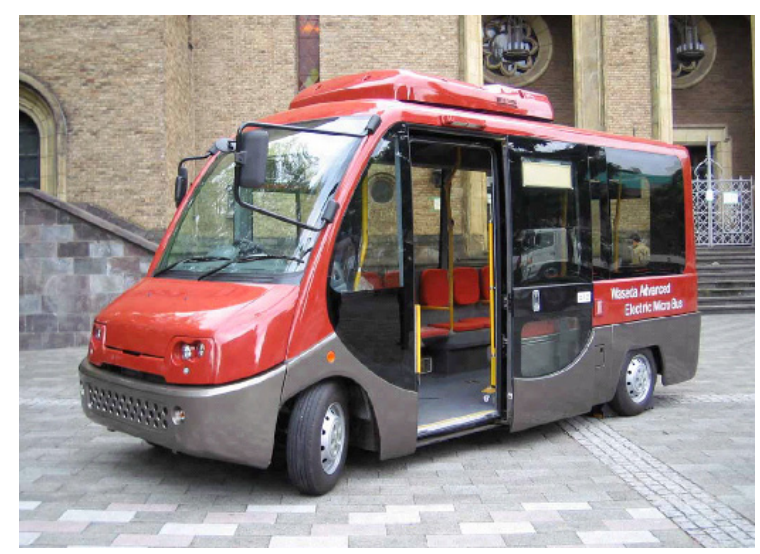

Figure 1: Waseda advanced Electric micro Bus

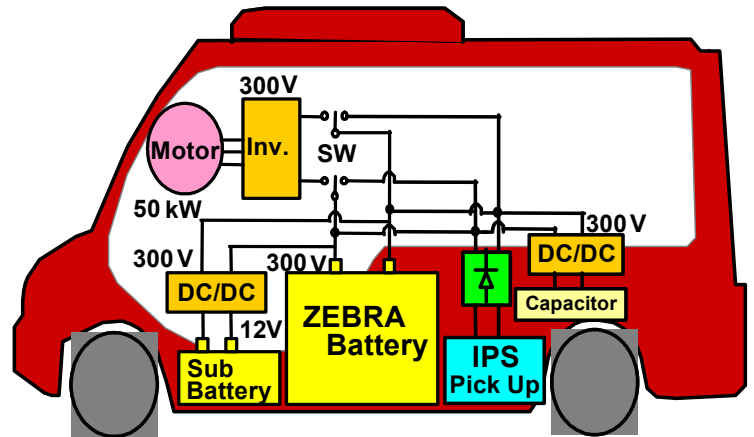

(a) WEB-1

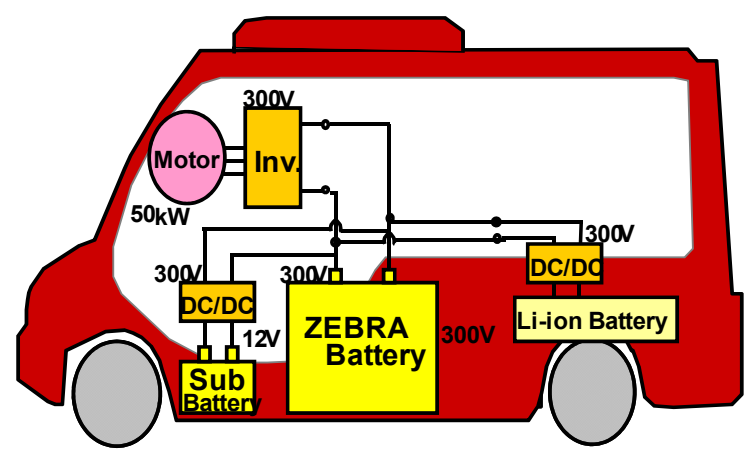

(b) WEB-2

Figure 2: Power system configuration of vehicle

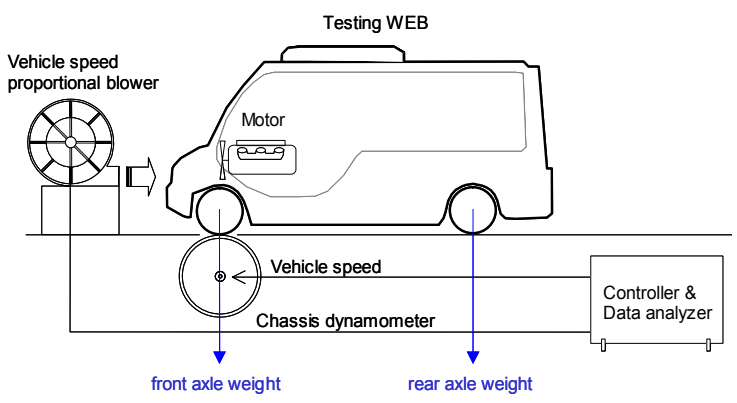

Figure 3: Test equipment on chassis dynamometer used with running experiment 


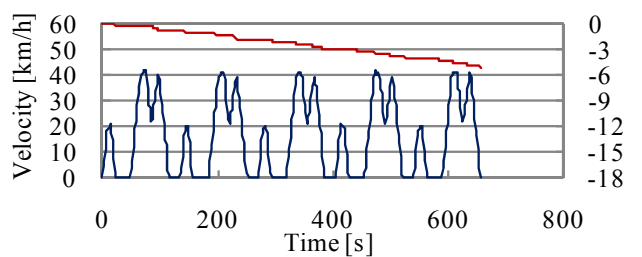

(a) M15 Mode

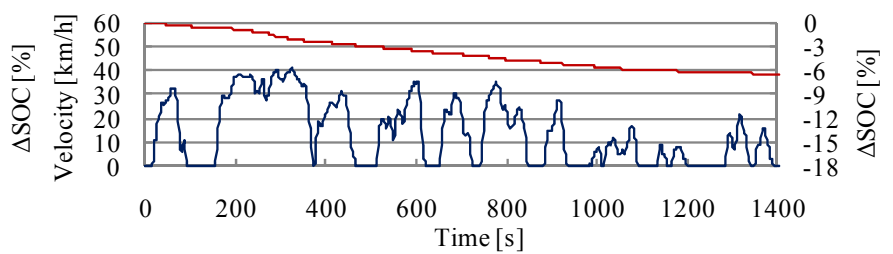

(b) Modified JE05 Mode

Figure 4: Variation of velocity and SOC of the tests (Blue line: velocity, Red line: state of charge (SOC) of WEB)

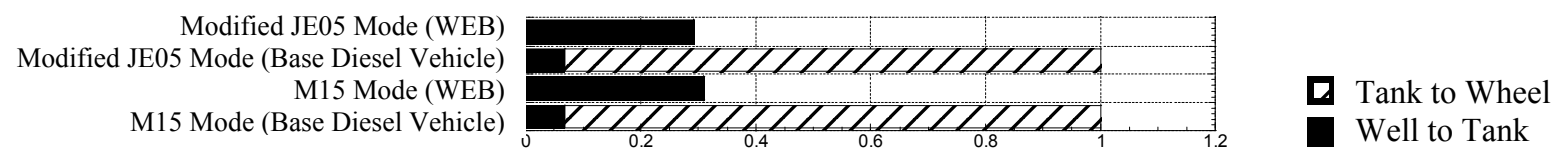

Figure 5: Relative performance of $\mathrm{CO}_{2}$ emissions of WEB compared with the base diesel vehicle

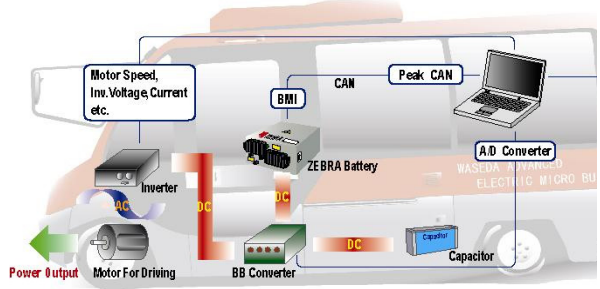

Figure 6: Conceptual diagram of data collection method
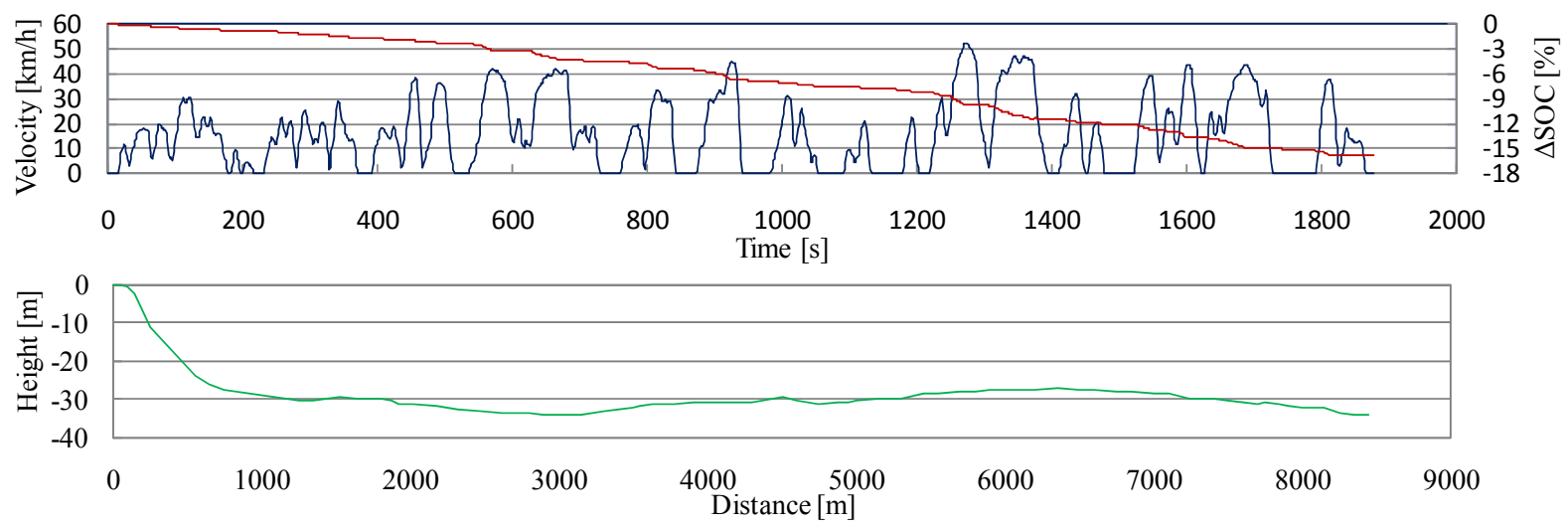

Figure 7: Variation of velocity, SOC and height (Honjo (2005))
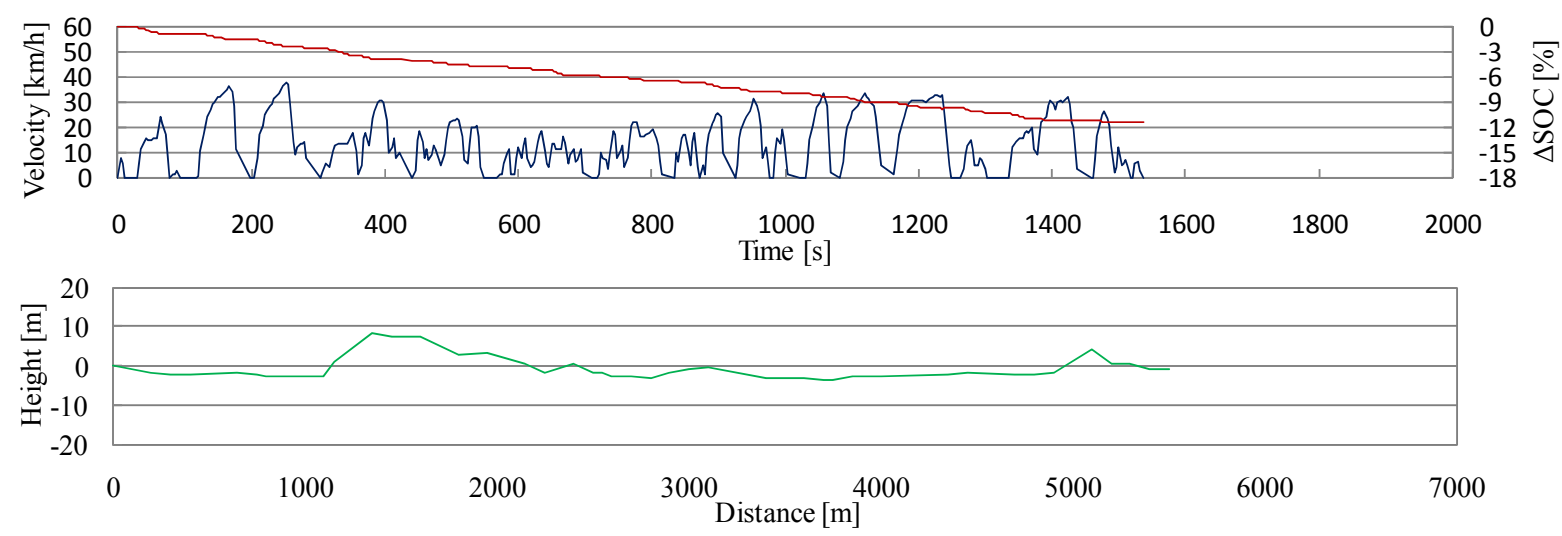

Figure 8: Variation of velocity, SOC and height (Yukarigaoka (Short Course)) 

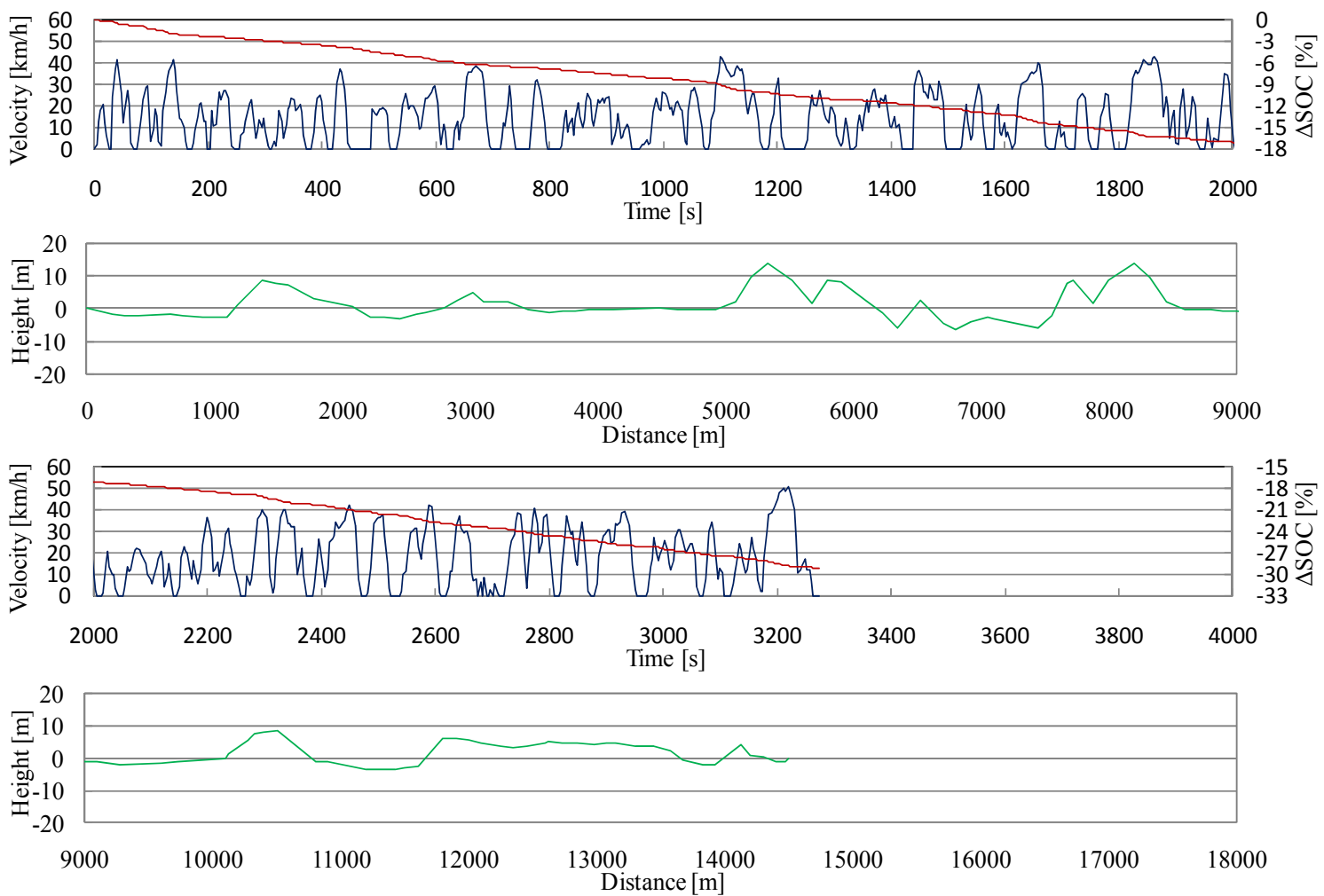

Figure 9: Variation of velocity, SOC and height (Yukarigaoka (Long Course))

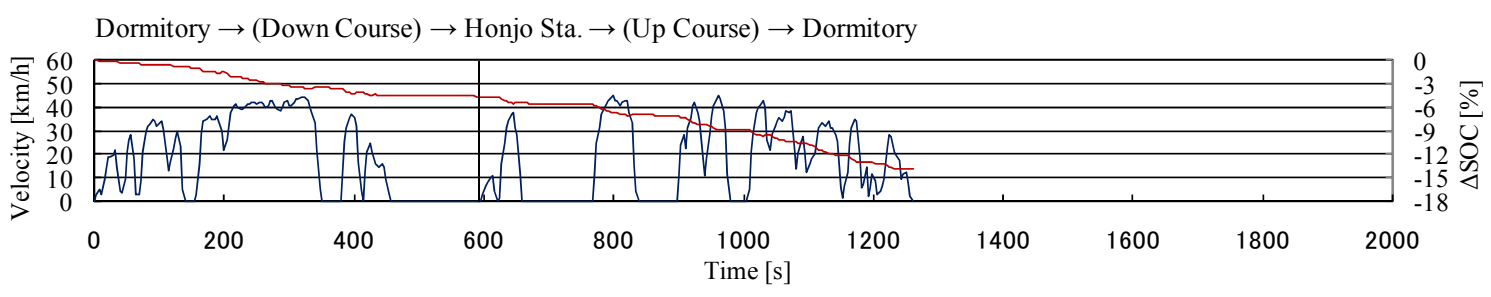

Dormitory $\rightarrow$ (Down Course) $\rightarrow$ Honjo Sta. $\rightarrow$ (Up Course) $\rightarrow$ Dormitory

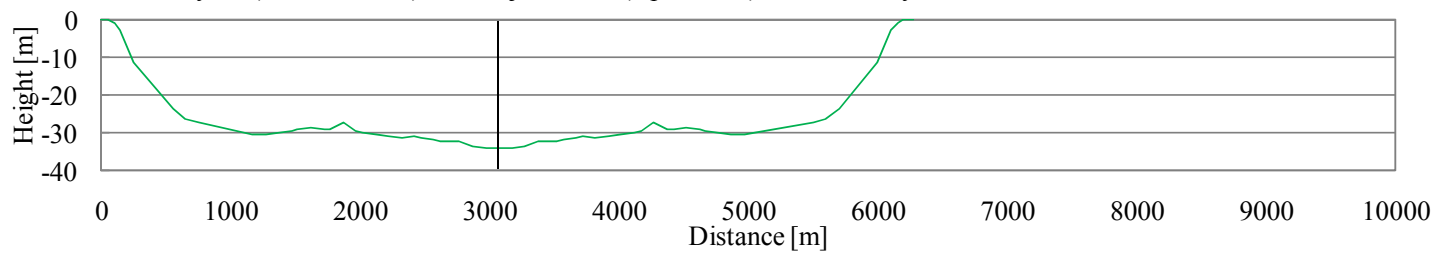

Figure 10: Variation of velocity, SOC and height (Honjo (2009))

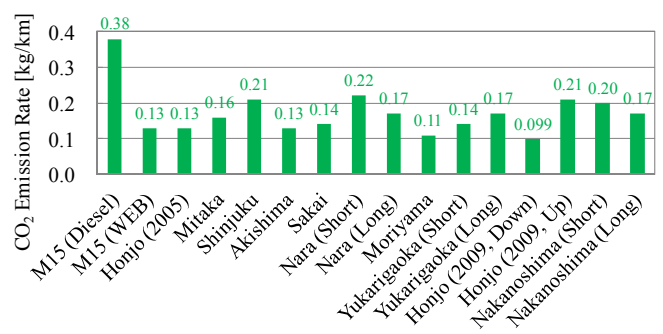

Figure 11: Comparison of $\mathrm{CO}_{2}$ emission rate (well-to-wheel) in each chassis dynamometer test and each test region

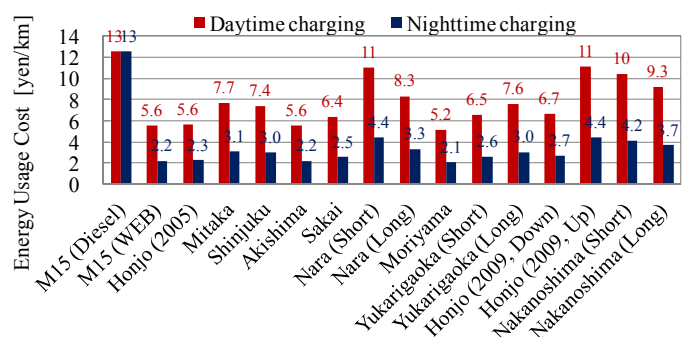

Figure 12: Comparison of energy usage cost per $1 \mathrm{~km}$ in each chassis dynamometer test and each test region 


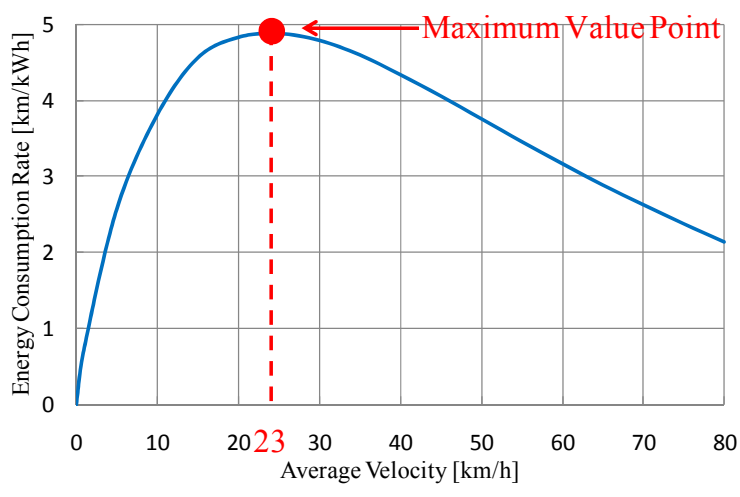

Figure 13: Relationship between average velocity and energy consumption rate per $1 \mathrm{kWh}$ of WEB

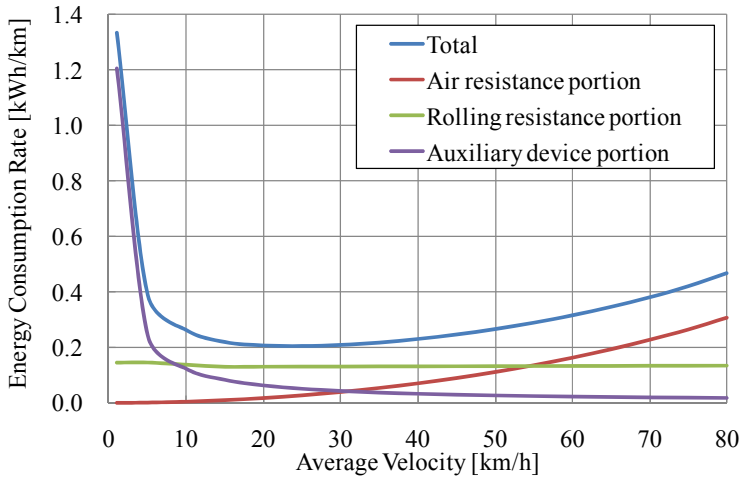

Figure 14: Relationship between average velocity and energy consumption rate per $1 \mathrm{~km}$ of WEB

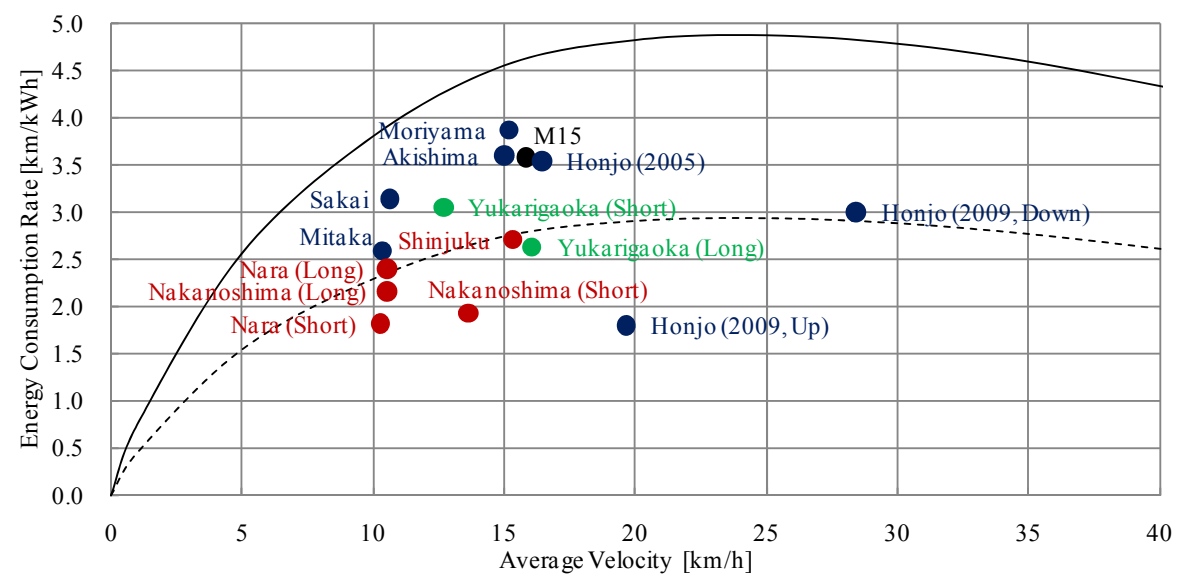

Figure 15: Comparison of actual measured values and simulation analysis values for energy consumption rate of WEB

Table 1: Specification of vehicle

\begin{tabular}{c|c|c|c|c}
\hline \multicolumn{2}{c|}{ Vehicle } & $\begin{array}{c}\text { Base Diesel Vehicle } \\
\text { (Poncho) }\end{array}$ & WEB-1 & WEB-2 \\
\hline \multicolumn{2}{c}{ Vehicle Mass } & $2805 \mathrm{~kg}$ & $3175 \mathrm{~kg}$ & $3175 \mathrm{~kg}$ \\
\hline \multirow{4}{*}{$\begin{array}{c}\text { Rotation } \\
\text { Machine }\end{array}$} & On Board Unit & Diesel 2.8LDI-TI & IPMSM & IPMSM \\
\cline { 2 - 5 } & Maximum Power & $93 \mathrm{~kW}(3600 \mathrm{rpm})$ & $50 \mathrm{~kW}$ & $50 \mathrm{~kW}$ \\
\cline { 2 - 5 } & Maximum Torque & $294 \mathrm{Nm}(1800 \mathrm{rpm})$ & $240 \mathrm{Nm}$ & $240 \mathrm{Nm}$ \\
\hline \multirow{4}{*}{$\begin{array}{c}\text { Main Battery } \\
\text { (Nickel Sodium }\end{array}$} & Energy Density & - & $105 \mathrm{Wh} / \mathrm{kg}$ & $118 \mathrm{Wh} / \mathrm{kg}$ \\
\cline { 2 - 5 } Chloride Battery) & Power Density & - & $180 \mathrm{~W} / \mathrm{kg}$ & $180 \mathrm{~W} / \mathrm{kg}$ \\
\cline { 2 - 5 } & Maximum Power & - & $32 \mathrm{~kW}$ & $32 \mathrm{~kW}$ \\
\cline { 2 - 5 } & Rated Voltage & - & $278 \mathrm{~V}$ & $278 \mathrm{~V}$ \\
\cline { 2 - 5 } & Capacity & - & $18.9 \mathrm{kWh}$ & $21.2 \mathrm{kWh}$ \\
\cline { 2 - 5 } & Mass & - & $180 \mathrm{~kg}$ & $180 \mathrm{~kg}$ \\
\hline \multirow{4}{*}{$\begin{array}{c}\text { Sub Battery } \\
\text { (WEB-1: Super Capacitor) } \\
(\text { WEB-2: Li-ion Battery) }\end{array}$} & Maximum Power & - & $55.7 \mathrm{~kW}$ & $54 \mathrm{~kW}$ \\
\cline { 2 - 5 } & Rated Voltage & - & $300 \mathrm{~V}$ & $259 \mathrm{~V}$ \\
\cline { 2 - 5 } & Capacity & - & $141.25 \mathrm{Wh}$ & $1100 \mathrm{Wh}$ \\
\hline
\end{tabular}


Table 2: Results of vehicle mode tests

\begin{tabular}{|c|c|c|c|}
\hline & & M15 Mode & Modified JE05 Mode \\
\hline \multirow{4}{*}{$\begin{array}{l}\text { WEB-1 with } \\
11 \text { persons } \\
(605 \mathrm{~kg})\end{array}$} & Travel Distance & $2.88 \mathrm{~km}$ & $5.4 \mathrm{~km}$ \\
\hline & Energy Consumption (Tank to Wheel) & $805 \mathrm{Wh}$ & $1160 \mathrm{Wh}$ \\
\hline & Energy Consumption Rate (Tank to Wheel) & $3.48 \mathrm{~km} / \mathrm{kWh}$ & $4.66 \mathrm{~km} / \mathrm{kWh}$ \\
\hline & $\mathrm{CO}_{2}$ Emissions (Well to Tank $=$ Well to Wheel) $*$ & $368 \mathrm{~g}$ & $530 \mathrm{~g}$ \\
\hline \multirow{4}{*}{$\begin{array}{l}\text { Base Diesel } \\
\text { Vehicle } \\
\text { (Poncho) with } \\
11 \text { persons } \\
(605 \mathrm{~kg})\end{array}$} & Fuel Consumption Rate (Tank to Wheel) & $7.42 \mathrm{~km} / \mathrm{L}$ & $9.09 \mathrm{~km} / \mathrm{L}$ \\
\hline & $\mathrm{CO}_{2}$ Emissions (Tank to Wheel) & $1010 \mathrm{~g}$ & $1550 \mathrm{~g}$ \\
\hline & $\mathrm{CO}_{2}$ Emissions (Well to Tank)** & $75.0 \mathrm{~g}$ & $115 \mathrm{~g}$ \\
\hline & $\mathrm{CO}_{2}$ Emissions (Well to Wheel) & $1085 \mathrm{~g}$ & $1665 \mathrm{~g}$ \\
\hline
\end{tabular}

* $0.375 \mathrm{~kg}-\mathrm{CO}_{2} / \mathrm{kWh}$, IPS Efficiency $\times$ Battery Charge Efficiency: $0.86 \times 0.95$

**Diesel Fuel (LHV): $35.5 \mathrm{MJ} / \mathrm{L}, 5.45 \mathrm{~g}-\mathrm{CO}_{2} / \mathrm{MJ}$

Table 3: Summary of characteristics of each test region

\begin{tabular}{|c|c|c|c|c|}
\hline Date & \multicolumn{2}{|c|}{ Test Region } & $\begin{array}{c}\text { Classification } \\
\text { of Region }\end{array}$ & $\begin{array}{c}\text { Running } \\
\text { Characteristics }\end{array}$ \\
\hline $\begin{array}{l}\text { Nov. } \\
2005\end{array}$ & \multicolumn{2}{|c|}{ Honjo-shi, Saitama } & $\begin{array}{l}\text { Urban area } \\
\text { (provincial) }\end{array}$ & $\begin{array}{l}\text { Region with almost no traffic congestion and } \\
\text { a run that included steep downhill sections }\end{array}$ \\
\hline $\begin{array}{l}\text { Nov. } \\
2006\end{array}$ & \multicolumn{2}{|c|}{ Mitaka-shi, Tokyo } & $\begin{array}{l}\text { Urban area } \\
\text { (city) }\end{array}$ & $\begin{array}{l}\text { Numerous bus stops were established (4.4 } \\
\text { stops } / \mathrm{km}) \text { on the assumption that it was a } \\
\text { community bus, running on flat roads }\end{array}$ \\
\hline $\begin{array}{l}\text { Sep. } \\
2007\end{array}$ & \multicolumn{2}{|c|}{ Shinjuku-ku, Tokyo } & $\begin{array}{l}\text { Urban area } \\
\text { (city) }\end{array}$ & Shuttle run on flat roads \\
\hline $\begin{array}{l}\text { Feb. } \\
2008\end{array}$ & \multicolumn{2}{|c|}{ Akishima-shi, Tokyo } & $\begin{array}{l}\text { Urban area } \\
\text { (provincial) }\end{array}$ & $\begin{array}{l}\text { Running on flat roads with almost no } \\
\text { traffic congestion }\end{array}$ \\
\hline $\begin{array}{l}\text { Oct. } \\
2008\end{array}$ & \multicolumn{2}{|c|}{ Sakai-shi, Osaka } & $\begin{array}{l}\text { Urban area } \\
\text { (provincial) }\end{array}$ & $\begin{array}{l}\text { Running on flat roads with almost no } \\
\text { traffic congestion }\end{array}$ \\
\hline \multirow{2}{*}{$\begin{array}{l}\text { Nov. } \\
2008\end{array}$} & \multirow{2}{*}{$\begin{array}{l}\text { Nara-shi, } \\
\text { Nara }\end{array}$} & Short Course & \multirow{2}{*}{$\begin{array}{l}\text { Urban area } \\
\text { (city) }\end{array}$} & $\begin{array}{l}\text { A circular run that included regions with } \\
\text { changes in elevation }\end{array}$ \\
\hline & & Long Course & & Shuttle run on flat roads \\
\hline $\begin{array}{l}\text { Nov. } \\
2008\end{array}$ & \multicolumn{2}{|c|}{ Moriyama-shi, Shiga } & $\begin{array}{l}\text { Urban area } \\
\text { (provincial) }\end{array}$ & $\begin{array}{l}\text { Running on flat roads with almost no } \\
\text { traffic congestion }\end{array}$ \\
\hline \multirow{2}{*}{$\begin{array}{l}\text { Apr. } \\
2009\end{array}$} & \multirow{2}{*}{$\begin{array}{l}\text { Yukarigaoka, } \\
\text { Sakura-shi, } \\
\text { Chiba }\end{array}$} & Short Course & \multirow{2}{*}{$\begin{array}{c}\text { Residential } \\
\text { area }\end{array}$} & $\begin{array}{l}\text { Numerous bus stops were established ( } 2.4 \\
\text { stops } / \mathrm{km}) \text { on the assumption that it was a } \\
\text { community bus, including low velocity } \\
\text { sections in residential areas with narrow roads, } \\
\text { running in regions with changes in elevation }\end{array}$ \\
\hline & & Long Course & & $\begin{array}{l}\text { Numerous bus stops were established (1.8 } \\
\text { stops } / \mathrm{km}) \text { on the assumption that it was a } \\
\text { community bus, including low velocity } \\
\text { sections in residential areas with narrow roads, } \\
\text { running in regions with changes in elevation }\end{array}$ \\
\hline \multirow{2}{*}{$\begin{array}{l}\text { Sep. } \\
2009\end{array}$} & \multirow{2}{*}{$\begin{array}{c}\text { Honjo-shi, } \\
\text { Saitama }\end{array}$} & Down Course & \multirow{2}{*}{$\begin{array}{l}\text { Urban area } \\
\text { (provincial) }\end{array}$} & $\begin{array}{l}\text { Almost no traffic congestion, but } \\
\text { temporary stops at long traffic lights, the } \\
\text { run included steep downhill sections }\end{array}$ \\
\hline & & Up Course & & $\begin{array}{l}\text { Almost no traffic congestion, but } \\
\text { temporary stops at long traffic lights, the } \\
\text { run included steep uphill sections }\end{array}$ \\
\hline \multirow{2}{*}{$\begin{array}{l}\text { Oct. } \\
2009\end{array}$} & \multirow{2}{*}{$\begin{array}{l}\text { Nakanoshima, } \\
\text { Kita-ku, } \\
\text { Osaka }\end{array}$} & Short Course & \multirow{2}{*}{$\begin{array}{l}\text { Urban area } \\
\text { (city) }\end{array}$} & Shuttle run on flat roads \\
\hline & & Long Course & & Running on flat roads \\
\hline
\end{tabular}


Table 4: Results of vehicle running tests in each test region

\begin{tabular}{|c|c|c|c|c|c|c|c|c|c|c|c|}
\hline & 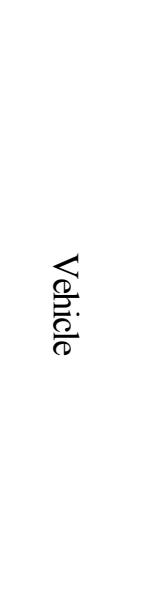 & 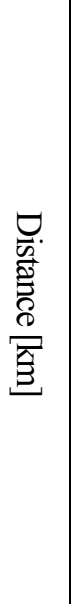 & 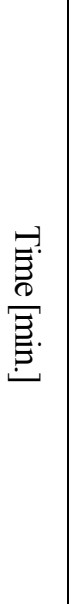 & 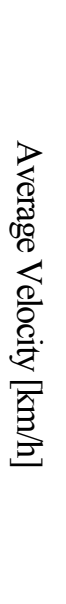 & 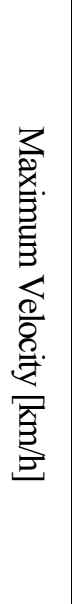 & 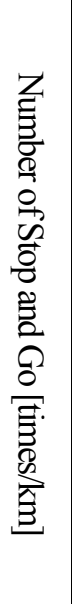 & 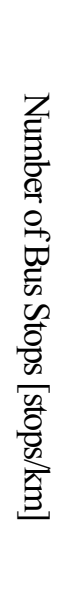 & 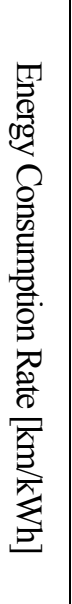 & 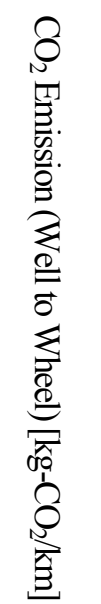 & 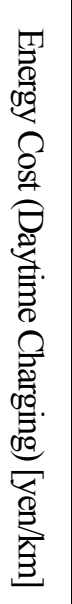 & 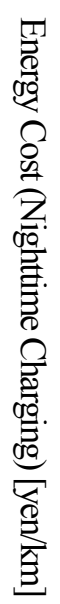 \\
\hline M15 Mode (Diesel)* & Poncho & 2.9 & 11 & 16 & 41 & 3.4 & - & - & 0.38 & 13 & 13 \\
\hline M15 Mode $(\text { WEB })^{*}$ & WEB-1 & 2.9 & 11 & 16 & 41 & 3.4 & 一 & 3.6 & 0.13 & 5.6 & 2.2 \\
\hline Modified JE05 Mode (Diesel)* & Poncho & 5.4 & 23 & 14 & 40 & 2.4 & 一 & 一 & 0.31 & 10 & 10 \\
\hline Modified JE05 Mode (WEB)* & WEB-1 & 5.4 & 23 & 14 & 40 & 2.4 & - & 4.5 & 0.098 & 4.4 & 1.8 \\
\hline Honjo (2005) & WEB-1 & 8.5 & 31 & 16 & 52 & 2.0 & 0.71 & 3.5 & 0.13 & 5.6 & 2.3 \\
\hline Mitaka & WEB-2 & 5.7 & 33 & 10 & 43 & 7.0 & 4.4 & 2.6 & 0.16 & 7.7 & 3.1 \\
\hline Shinjuku & WEB-2 & 4.6 & 18 & 15 & 50 & 1.3 & 0.43 & 2.7 & 0.21 & 7.4 & 3.0 \\
\hline Akishima & WEB-1 & 9.0 & 36 & 15 & 41 & 2.2 & 1.1 & 3.6 & 0.13 & 5.6 & 2.2 \\
\hline Sakai & WEB-2 & 11 & 62 & 11 & 43 & 3.9 & 0.55 & 3.1 & 0.14 & 6.4 & 2.5 \\
\hline Nara (Short Course) & WEB-1 & 6.0 & 35 & 10 & - & - & 1.0 & 1.8 & 0.22 & 11 & 4.4 \\
\hline Nara (Long Course) & WEB-1 & 10 & 57 & 11 & 一 & - & 0.40 & 2.4 & 0.17 & 8.3 & 3.3 \\
\hline Moriyama & WEB-2 & 19 & 75 & 15 & 52 & 2.2 & 0.58 & 3.9 & 0.11 & 5.2 & 2.1 \\
\hline Yukarigaoka (Short Course) & WEB-1 & 5.5 & 26 & 13 & 38 & 3.6 & 2.2 & 3.1 & 0.14 & 6.5 & 2.6 \\
\hline Yukarigaoka (Long Course) & WEB-2 & 15 & 56 & 16 & 51 & 3.0 & 1.8 & 2.6 & 0.17 & 7.6 & 3.0 \\
\hline Honjo (2009, Down Course) & WEB-2 & 3.6 & 7.6 & 28 & 45 & 1.1 & 一 & 3.0 & 0.099 & 6.7 & 2.7 \\
\hline Honjo (2009, Up Course) & WEB-2 & 3.6 & 11 & 20 & 45 & 1.4 & - & 1.8 & 0.21 & 11 & 4.4 \\
\hline Nakanoshima (Short Course) & WEB-2 & 2.5 & 11 & 14 & 30 & 3.2 & 0.80 & 1.9 & 0.20 & 10 & 4.2 \\
\hline Nakanoshima (Long Course) & WEB-2 & 16 & 91 & 11 & 33 & 2.7 & 0.37 & 2.2 & 0.17 & 9.3 & 3.7 \\
\hline
\end{tabular}

\section{References}

[1] Y. Daisho, Y. Kamiya, K. Narusawa, et al., Fuel Cell Vehicles, Sankaido, ISBN 4-381-08848-4, 2005.

[2] M. Hayashida, K. Narusawa and Y. Kamiya, Electricity Flow Analysis in the Series Hybrid System by the Charge discharge Tester, Society of Automotive Engineers (SAE) paper, 2001-010784, 2001, pp: 1-7.

[3] Y. Kamiya, Y. Daisho, F. Kuwabara and S. Takahashi, Development and Performance
Evaluation of an Advanced Electric Micro Bus Transportation System, Report No. 1: Development and Performance Evaluation of Waseda Advanced Electric Micro Bus, JSAE Annual Spring Congresses, 20065314, 2006.

[4] TOYOTA MOTOR CORPORATION and Mizuho Information \& Research Institute, Inc., Well-toWheel Analysis of Greenhouse Gas Emissions of Automotive Fuels in the Japanese Context - Well-toTank Report -, Download at: http://www.mizuhoir.co.jp/english/knowledge/ report/pdf/wtwgh g041130.pdf, Nov. 2004, pp: 7-10. 


\section{Authors}

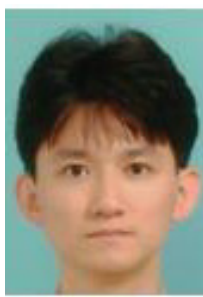

\section{Yushi Kamiya}

Waseda University, 55S-704, 3-4-1 Ohkubo, Shinjuku, Tokyo, JAPAN

Y. Kamiya received the B., M. and D.

Eng. degrees from Waseda University. $\mathrm{He}$ is presently professor at Waseda University.

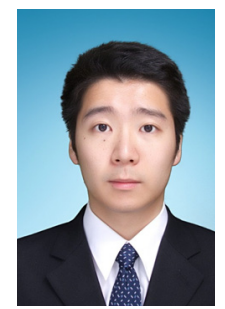

\section{Kimihiko Sato}

Waseda University, 55S-704, 3-4-1 K. Sato received the B. Eng. degree from Chuo University, and M. Eng. degree from Waseda University.

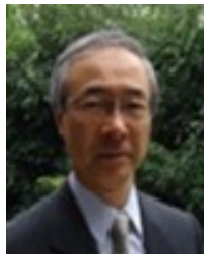

\section{Yasuhiro Daisho}

Waseda University, 55S-704, 3-4-1 Ohkubo, Shinjuku, Tokyo, JAPAN Y. Daisho graduated the doctor's course of Waseda University. He is presently professor at Waseda University. 